p-ISSN: $2338-4794$

e-ISSN: 2579-7476

Vol.8. No. 3 September-Desember 2020

\title{
PENGARUH STRUKTUR ASET, PERTUMBUHAN PENJUALAN DAN KEPEMILIKAN MANAJERIAL TERHADAP KEBIJAKAN HUTANG (Studi pada perusahaan Pertambangan sub sektor batubara yang terdaftar pada Indeks Kompas 100 periode 2013-2018)
}

\author{
Jombrik TPR *) \\ *) Dosen Fakultas Ekonomi Universitas Darma Persada
}

\begin{abstract}
This study aims to determine the effect of asset structure, sales growth, and managerial ownership on debt policy. This research was conducted at companies in the coal sub-sector mining sector. The analytical method used in this research is multiple linear regression. The results of the research on asset structure have a positive and significant effect on debt policy, sales growth does not have a significant effect on debt policy and managerial ownership has no significant effect on debt policy in the coal mining sub-sector companies. The three variables of asset structure, sales growth, and managerial ownership simultaneously have a significant effect on debt policy in the coal mining sector sub-sector, which means that these three variables are considered by companies in making debt policies.
\end{abstract}

Keywords: Asset structure, sales growth, managerial ownership, debt policy.

\section{PENDAHULUAN}

Tujuan utama didirikannya perusahaan adalah untuk mendapatkan laba, karena laba yang besar memungkinkan perusahaan mampu mempertahankan kelangsungan hidupnya (going concern). Dalam prespektif keuangan, menjaga kelangsungan hidup perusahaan menjadi salah satu tujuan. Selain itu, perusahaan tidak hanya dituntut untuk menghasilkan laba yang besar, tetapi yang paling utama adalah memakmurkan pemegang saham. Nilai perusahaan merupakan cerminan kinerja perusahaan secara makro, karena nilai perusahaan dapat menggambarkan kapitalisasi didalam perusahaan. Meningkatnya nilai perusahaan merupakan indikator bahwa kinerja perusahaan dalam keadaan yang baik. Struktur aset dalam perusahaan sangat dipengaruhi oleh bagaimana perusahaan tersebut didanai. Kebijakan pendanaan merupakan salah satu kebijakan yang sangat penting bagi perusahaan, karena menyangkut perolehan sumber dana untuk kegiatan operasional perusahaan (Farah, 2016). Kebijakan pendanaan ini akan berpengaruh terhadap faktor leverage perusahaan, baik leverage Operasi maupun leverage keuangan. Jika perusahaan menetapkan kebijakan untuk menggunakan sumber dana dari hutang, berarti leverage keuangan perusahaan akan meningkat dan perusahaan akan menanggung biaya tetap berupa bunga yang harus dibayarkan.

Sumber dana yang digunakan oleh perusahaan dalam usaha memenuhi kebutuhan dapat bersumber dari dalam perusahaan (internal source). Dana dari dalam perusahaan dapat diartikan sebagai bentuk dana yang berasal dari dalam perusahaan itu sendiri, dengan kata lain, dana dengan kekuatan atau kemampuan sendiri. Dana dari dalam perusahaan dapat menggunakan cadangan laba dari sebagian sisa hasil usaha yang merupakan unsur dana sendiri. Kedua sumber dana dari luar perusahaan (external source), yaitu 
pemenuhan kebutuhan dana yang diambil atau berasal dari sumber-sumber dana yang ada di luar perusahaan. Sumber dana tersebut dapat berasal dari pihak bank, asuransi, dan kreditur lainnya (Riyanto, dalam Nuraini, 2015).

Pengambilan keputusan pendanaan melalui hutang menjadi perhatian yang serius bagi pihak pengelola perusahaan, karena penggunaan hutang akan diikuti oleh resiko yang dihadapi. Namun seringkali pihak manajer perusahaan mempunyai tujuan lain yang bertentangan dengan tujuan utama tersebut, keputusan yang diambil manajer cenderung untuk melindungi dan memenuhi kepentingan mereka terlebih dahulu daripada memenuhi kepentingan pemilik. Salah satu alternatif manajer untuk memperoleh dana adalah melalui hutang. Jadi diperlukan tingkat hutang yang optimal pada titik tertentu agar nilai perusahaan naik dan tidak timbul biaya kebangkrutan. Adanya resiko kebangkrutan pada penggunaan hutang membuat manajemen perusahaan harus mempertimbangkan faktor-faktor yang mempengaruhi penggunaan hutang, diantaranya faktor struktur aset, faktor pertumbuhan penjualan dan faktor kepemilikan manajerial (Surya dan Rahayuningsih, 2012).

Struktur aset merupakan kekayaan perusahaan yang diharapkan dapat memberikan manfaat di masa yang akan datang yang merupakan perimbangan atau perbandingan antara aset tetap dan total aset. Trade off theory menjelaskan bahwa perusahaan yang sebagian besar asetnya berasal dari aset tetap, maka akan mengutamakan pemenuhan kebutuhan dananya dengan hutang dibandingkan dengan modal sendiri, karena aset tetap, seperti tanah dan bangunan, dapat dijadikan jaminan untuk menutupi hutanghutangnya. Hal ini sesuai dengan Brigham dan Houston (2011) yang menyatakan bahwa secara umum perusahaan yang memiliki jaminan terhadap hutang akan lebih mudah mendapatkan hutang daripada perusahaan yang tidak memiliki jaminan.
Sektor energi merupakan salah satu penopang pembangunan ekonomi suatu negara, karena perannya sebagai penyedia sumber daya energi yang sangat diperlukan bagi pembangunan ekonomi suatu negara. Potensi Indonesia yang kaya akan sumber daya alam menjadi daya tarik perusahaan-perusahaan untuk melakukan eksplorasi sumber daya tersebut, namun kondisi ekonomi global yang berfluktuatif beberapa tahun ini membuat masalah pendanaan menjadi masalah utama perusahaan berskala besar. Masalah tersebut juga dihadapi oleh sektor pertambangan di indonesia.

Tujuan penelitian ini adalah untuk menganalisis pengaruh, struktur aset, pentumbuhan penjualan dan kepemilikan manajerial terhadap kebijakan hutang.

\section{LANDASAN TEORI}

\section{Struktur Aset}

Pada umumnya terdapat dua jenis aset yang dimiliki perusahaan, yaitu aset lancar dan aset tetap. Aset tetap dapat dijadikan pertimbangan jaminan oleh kreditor dalam memberi pinjaman. Besarnya aset tetap suatu perusahaan dapat menentukan besarnya penggunaan hutang. Perusahaan yang memiliki aset tetap dalam jumlah besar dapat menggunakan hutang dalam jumlah besar karena aset tersebut dapat digunakan sebagai jaminan pinjaman (Susanti, 2014).

Menurut Kasmir (2011), aset (assets) merupakan harta atau kekayaan yang dimiliki perusahaan, baik pada saat tertentu maupun periode tertentu, sedangkan menurut Santoso (2009) Aset adalah manfaat ekonomis yang sangat mungkin diperoleh atau dikendalikan oleh perusahaan pada masa yang akan datang sebagai akibat dari transaksi atau kejadian masa lalu. Aset terdiri dari aset moneter (monetery assets), seperti uang tunai (kas), surat-surat berharga (security) yang segera dapat dijual, tagihan-tagihan (piutang), dan aset non-moneter (nonmonetery 
assets), seperti persediaan, asuransi dibayar dimuka, mesin-mesin dan peralatan, paten, serta biaya-biaya yang dapat dipulihkan dan dialokasi secara tepat pada pendapatan pada periode yang akan datang.

Struktur aset merupakan perbandingan antara aset tetap dengan total aset atau aset perusahaan. Aset sendiri merupakan bagian yang digunakan untuk keperluan operasi perusahaan, sedangkan menurut Mamduh dalam Dwi, et al (2013), struktur aset adalah penentuan berapa besar alokasi untuk masing-masing komponen aset, baik dalam aset lancar maupun dalam aset tetap. Perusahaan yang asetnya memadai untuk digunakan sebagai jaminan pinjaman cenderung akan cukup banyak menggunakan hutang (Brigham dan Houston, 2011).

Perusahaan yang memiliki aset tetap dalam jumlah besar dapat menggunakan hutang dalam jumlah besar, karena aset tersebut dapat digunakan sebagai jaminan pinjaman. Ita (2016), Surya dan Rahayuningsih (2012) menemukan bahwa struktur asset berpengaruh positif terhadap kebijakan hutang, namun berbeda dengan penelitian Meivita (2018) yang menemukan bahwa struktur asset tidak berpengaruh signifikan terhadap kebijakan hutang.

\section{Pertumbuhan Penjualan}

Menurut Kesuma dalam Hidayat (2013), pertumbuhan penjualan (growth sales) adalah kenaikan jumlah penjualan dari tahun ke tahun atau dari waktu ke waktu. Perusahaan yang memiliki tingkat pertumbuhan penjualan yang tinggi akan membutuhkan lebih banyak investasi pada berbagai elemen aset, baik aset tetap maupun aset lancar. Pihak manajemen perlu mempertimbangkan sumber pendanaan yang tepat bagi pembelanjaan aset tersebut. Perusahaan yang memiliki pertumbuhan penjualan yang tinggi akan mampu memenuhi kewajibannya seandainya perusahaan tersebut mendanai asetnya dengan hutang, begitu pula sebaliknya. Menurut Fabozzi dalam Pradhana, et al (2014) menyatakan bahwa pertumbuhan penjualan adalah perubahan penjualan pada laporan keuangan pertahun. Pertumbuhan penjualan yang di atas rata-rata suatu perusahaan pada umumnya didasarkan pada pertumbuhan cepat yang diharapkan dari industri dimana perusahan beroperasi.

Pendapatan yang dihasilkan dari penjualan akan dapat digunakan untuk mengukur tingkat pertumbuhan penjualan. Jadi perusahaan dengan tingkat penjualan dan laba yang tinggi kecenderungan perusahaan tersebut menggunakan hutang sebagai sumber dana eksternal yang lebih besar dibandingkan perusahaanperusahaan yang tingkat penjualannya rendah. Pertumbuhan penjualan juga merupakan indikator permintaan dan daya saing perusahaan dalam suatu industri. Hidayat (2013) menyatakan jika penjualan meningkat per tahun, maka pembiayaan yang berasal dari utang dengan beban tertentu akan meningkatkan pendapatan pemegang saham. Hal ini mendorong perusahaan dengan tingkat penjualan yang tinggi akan cenderung menggunakan jumlah hutang yang lebih besar dibandingkan dengan perusahaanperusahaan yang tingkat pertumbuhan penjualannya rendah. Hasil penelitian Hidayat (2013) Mardiyati (2018) menyatakan pertumbuhan penjualan berpengaruh positif terhadap kebijakan hutang, namun berbeda dengan penelitian Susanti (2014) yang menyatakan bahwa pertumbuhan penjualan tidak berpengaruh terhadap kebijakan hutang.

\section{Kepemilikan Manajerial}

Kepemilikan manajerial adalah persentase kepemilikan saham oleh pihak manajemen yang secara aktif ikut dalam pengambilan keputusan perusahaan. Dalam teori keagenan hubungan antara manajer dan pemegang saham digambarkan sebagai hubungan antara agen dan principal (Schroeder, et al, 
2001). Menurut Sujoko dan Soebiantoro dalam Nuraini (2015), kepemilikan manajerial (managerial ownership) adalah kepemilikan saham oleh pihak manajemen perusahaan yang diukur dengan persentase jumlah saham yang dimiliki oleh manajemen.

\section{Kepemilikan}

manajerial menggambarkan suatu peran ganda yaitu sebagai manajer dan juga pemegang saham dimana masing-masing memiliki kepentingan. Perbedaan kepentingan antar keduanya seringkali menimbulkan suatu konflik yang disebut konflik keagenan. Konflik keagenan ini dapat diminimalisir dengan cara meningkatkan kepemilikan saham oleh manajemen, kemudian meningkatkan dividend payout ratio yang akan dibagikan. Namun untuk memenuhi keduanya akan membutuhkan sumber pendanaan yang cukup besar. Sumber pendanaan eksternalpun seringkali menjadi alternatif untuk ditempuh. Pada dasarnya prinsipal dan agen memiliki kepentingan yang tidak jauh beda, yaitu untuk meningkatkan kesejahteraan masing-masing pihak. Dengan adanya kepentingan yang hampir sama tersebut, prinsipal dan agen cenderung akan lebih berhati-hati dalam penggunaan hutang, mengingat risiko yang muncul secara tidak langsung akan menjadi risiko prinsipal dan agen. Prinsipal dan agen cenderung memiliki perilaku untuk mengurangi tingkat hutang perusahaan.

Hasil penelitian Sheisarvian, et al (2015), dan Larasati (2011) menyatakan bahwa kepemilikan manajerial berpengaruh terhadap kebijakan hutang, bertolak belakang dengan hasil penelitian Warapsari (2016), dan Nuraini (2015) yang menyatakan bahwa kepemilikan manajerial tidak memiliki pengaruh terhadap kebijakan hutang.

\section{Kebijakan Hutang}

Hutang merupakan semua kewajiban keuangan perusahaan kepada pihak lain yang belum terpenuhi, di mana hutang ini merupakan sumber dana atau modal perusahaan yang berasal dari kreditur. Hutang jangka panjang memiliki tiga karakteristik, yaitu cepat, fleksibel, dan biaya rendah. Biaya administrasi menjadi relatif kecil, dan tidak diperlukan adanya persetujuan dengan pengawas pasar modal, seperti halnya jika perusahaan mengeluarkan obligasi. Hal ini dikarenakan pihak peminjam bernegosiasi langsung dengan kreditur (Sartono, 2008). Perusahaan dengan prospek yang menguntungkan akan mencoba menghindari penjualan saham dan mengusahakan modal baru dengan caracara lain, seperti dengan menggunakan hutang. Perusahaan dengan prospek yang kurang menguntungkan akan cenderung untuk menjual sahamnya (Brigham dan Houston, 2001).

Menurut Brigham dan Houston (2001), pengumuman emisi saham oleh suatu perusahaan umumnya merupakan suatu isyarat (signal) bahwa manajemen memandang prospek perusahaan tersebut suram. Apabila suatu perusahaan menawarkan penjualan saham baru lebih sering dari biasanya, maka harga sahamnya akan menurun, karena menerbitkan saham baru berarti memberikan isyarat negatif yang kemudian dapat menekan harga saham sekalipun prospek perusahaan cerah. Sebagaimana model Ross (1977) dalam Muliyanti (2010) mengembangkan model tentang penggunaan hutang merupakan isyarat yang disampaikan oleh manajer ke pasar. Apabila manajer mempunyai keyakinan bahwa prospek perusahaan baik, dan ingin agar harga saham meningkat, perusahaan ingin mengkomunikasikan hal tersebut ke investor. Manajer dapat menggunakan hutang lebih banyak, sebagai sinyal yang lebih dapat dipercaya. Hal ini karena perusahaan yang meningkatkan hutang bisa dipandang sebagai perusahaan yang yakin dengan prospek perusahaan di masa mendatang. Dasar pertimbangannya adalah penambahan hutang menyebabkan keterbatasan arus kas dan meningkatnya 
biaya-biaya yang akan menambah beban keuangan, sehingga manajer hanya akan menerbitkan hutang baru yang lebih banyak apabila manajer yakin perusahaan kelak dapat memenuhi kewajibannya. Investor diharapkan akan menangkap sinyal bahwa perusahaan mempunyai prospek yang baik. Dengan demikian hutang merupakan tanda atau sinyal positif.

Berbeda dengan teori pecking order, para manajer konsisten dengan tujuan utama perusahaan, yaitu memakmurkan kekayaan pemegang saham. Pada teori ini menyatakan bahwa perusahaan cenderung lebih memilih pendanaan yang berasal dari internal perusahaan daripada eksternal. Penggunaan pendanaan eksternal dilakukan apabila dana internal perusahaan tidak mencukupi. Urutan yang dikemukakan dalam teori ini adalah laba ditahan, hutang, dan saham preferen serta yang terakhir adalah saham biasa. Urutan pendanaan ini menunjukkan bahwa pendanaan ini berdasarkan tingkat risiko atas keputusan dan biaya atas sumber pendanaan dari mulai yang termurah hingga yang paling mahal (Sartono, 2001).

Kebijakan hutang yang diambil oleh pihak manajemen dalam rangka memperoleh sumber pembiayaan bagi perusahaan digunakan untuk membiayai aktivitas operasional perusahaan. Selain itu, menurut pemegang saham kebijakan hutang juga berfungsi sebagai mekanisme monitoring terhadap tindakan manajer yang dilakukan dalam pengelolaan perusahaan. Kebijakan hutang akan memberikan dampak pada pendisiplinan manajer untuk mengoptimalkan penggunaan dana yang ada karena dengan adanya hutang, maka perusahaaan akan melakukan pembayaran secara periodik atas bunga dan pokok pinjaman. Kesulitan keuangan dan atau risiko kebangkrutan akan timbul apabila perusahaan memiliki hutang yang cukup besar. Kebijakan hutang biasa diukur dengan debt to equity ratio.

\section{Hipotesis}

Berdasarkan latar belakang dan tujuan penelitian ini serta penelitian sebelumnya, tentang struktur aset, petumbuhan penjualan, kepemilikan manajerial dan pengaruhnya terhadap kebijakan hutang, hipotesis dalam penelitian ini adalah sebagai berikut;

1. Struktur aset berpengaruh signifikan terhadap kebijakan hutang dengan asumsi pertumbuhan penjualan dan kepemilikan manajerial tidak berubah.

2. Pertumbuhan penjualan berpengaruh signifikan terhadap kebijakan hutang dengan asumsi struktur aset dan kepemilikan manajerial tidak berubah.

3. Kepemilikan manajerial berpengaruh signifikan terhadap kebijakan hutang dengan asumsi struktur asset dan pertumbuhan penjualan tidak berubah.

\section{METODE PENELITIAN}

Penelitian ini menggunakan pendekatan kuantitatif, jenis penelitian yang digunakan adalah statistik deskriptif dan sifat penelitian yang digunakan adalah bersifat kausal. Syarat dalam menggunakan model regresi berganda dengan metode Ordinary Least Square (OLS) adalah terpenuhinya semua asumsi klasik agar hasil pengujian tidak bersifat bias dan efisien. Uji asumsi klasik yang dilakukan dalam penelitian ini adalah uji normalitas, uji autokorelasi, uji multikolinearitas dan uji heteroskedastisitas. Metode analisis data menggunakan analisis regresi linier berganda. Model regresi linier berganda yang digunakan adalah:

$Y=a+b_{1} X_{1}+b_{2} X_{2}+b_{3} X_{3}$

di mana;

$\mathrm{Y} \quad=$ Kebijakan hutang

$\mathrm{X}_{1} \quad=$ Struktur aset

$\mathrm{X}_{2} \quad=$ Pertumbuhan penjualan

$\mathrm{X}_{3} \quad=$ Kepemilikan manajerial 
a $=$ Konstanta

$\mathrm{b}_{\mathrm{i}} \quad=$ Koefisien regresi $(\mathrm{i}=1,2,3)$

Sampel penelitian ini diambil dengan menggunakan metode purposive sampling dengan keriteria, seluruh perusahaan pertambangan yang menyampaikan dan mempublikasikan laporan keuangan tahunan serta memiliki informasi yang menjadi variabel dalam penelitian ini. Perusahaan pertambangan pada Indeks Kompas 100 berjumlah 13 perusahaan. Dari 13 perusahaan tersebut terdapat 5 perusahaan yang dapat dijadikan sampel dengan periode data 6 tahun, sehingga $\mathrm{N}=30$. Kelima perusahaan tersebut adalah PT. Harum Energy Tbk, PT. Vale Indonesia Tbk, PT. Indo Tambangraya Megah Tbk, PT. Bukit Asam Adaro Energy Tbk.

\section{HASIL DAN PEMBAHASAN}

\section{Hasil Penelitian}

\section{Deskriptif variabel penelitian}

Analisis deskriptif atau statistik deskriptif dimksudkan untuk mendapatkan gambaran atau deskripsi tentang variabel yang digunakan dalam penelitian yaitu pertumbuhan penjualan, struktur aset, kepemilikan manajerial dan kebijakan hutang. penelitian yang terdiri kebijakan hutang, ukuran perusahaan, profitabilitas, dan pertumbuhan penjualan yang menggambarkan nilai variabel maksimum maupun minimum dan standar deviasinya.

\section{Hasil uji normalitas data}

Hasil uji normalitas menggunakan analisis non-parametrik Kolmogorov Smirnov (KS) one-sample KolmogorovSmirnov test diperoleh hasil bahwa unstandardized residual model penelitian ini mempunyai tingkat signifikansi 0,200 yang berarti lebih besar dari 0,05. Dengan demikian, dapat disimpulkan bahwa variabel-variabel yang digunakan terdistribusi secara normal. Dari output hasil one sample Kolmogorov Smirnov test ditunjukkan oleh nilai asymp.sig (2-tailed). diketahui bahwa nilai signifikasi (Asymp. Sig 2-Tailed) adalah 0,200. Karena nilai signifikasinya lebih dari 0,05 maka dapat disimpulkan bahwa data dalam penelitian ini telah terdistribusi secara normal.

\section{Hasil uji autokorelasi}

Berdasarkan nilai Durbin-Watson sebesar 2,224, sehingga du $(1,650)<$ Durbin Watson $(2,224)<4-d u$ $(2,350)$. Dapat disimpulkan bahwa dalam model regresi ini tidak terdapat autokolerasi dan model dapat digunakan.

\section{Hasil uji multikolenioritas}

Hasil uji menunjukan bahwa model regresi terbebas dari gejala mulitikolinearitas, ditunjukkan dari nilai tolerance setiap variable bebas, yaitu pertumbuhan penjualan dan perputaran total asset $>0,10$ dan nilai VIF (Varian Inflatation Factor) $<10$.

\section{Hasil uji heterokedastisitas}

Ciri-ciri data sampel tidak terjadi gejala heteroskedastisitas adalah titik-titik data tersebar di atas dan di bawah atau disekitar angka 0. Titik-titik data sampel tersebar di atas dan di bawah atau di sekitaran angka 0, dapat disimpulkan bahwa data sampel penelitian ini tidak terjadi gejala heteroskedastisitas. Hasil heterokedastitas menunjukkan bahwa data penelitian terbebas dari masalah heterokedastisitas. Hal tersebut dapat dilihat pada penyebaran data observasi

\section{Analisis regresi linear berganda}

Analisis regresi linear berganda digunakan untuk mengetahui hubungan positif atau negatif dari variabel bebas dangan variabel terikat dengan data berskala interval atau rasio. Persamaan regresi linear berganda adalah sebagai berikut;

$\mathrm{Y}=0,037+0,742 \mathrm{X}_{1}+0,251 \mathrm{X}_{2}+0$, $182 X_{3}$ 
Nilai F-hitung sebesar 4,140 lebih besar dari F-tabel 2,92 artinya struktur aset, pertumbuhan penjualan, dan kepemilikan manajerial secara bersamasama berpengaruh terhadap nilai kebijakan hutang. Koefisien determinasi yang disesuaikan (adjusted $R^{2}$ ) sebesar 0,245 yang berarti bahwa ketiga variabel independen mampu menjelaskan perubahan variabel dependen sebesar 24,5\%, sedangkan sisanya sebesar $75,5 \%$ dijelaskan oleh variabel lain diluar variabel penelitian ini.

Nilai konstanta $(\alpha)$ sebesar 0,037 , hal ini menunjukkan apabila variabel struktur aset $\left(\mathrm{X}_{1}\right)$, pertumbuhan penjualan $\left(\mathrm{X}_{2}\right)$, dan kepemilikan manajerial $\left(\mathrm{X}_{3}\right)$ bernilai nol , maka nilai kebijakan hutang (Y) naik 3,7\%.

Hasil uji hipotesis struktur aset menunjukkan hasil t-hitung sebesar 2,676 dengan t-tabel 2,056 atau t-hitung $2,676>$ t-tabel 2,042 dan nilai signifikansi sebesar 0,013 yang berarti lebih kecil dari probabilitas 0,05 atau $0,013<0,05$, maka hipotesis $\mathrm{H}_{1}$ diterima. berarti variabel independen struktur aset berpengaruh positif dan signifikan terhadap kebijakan hutang. Nilai koefisien struktur aset bernilai positif 0,742 , yang berarti bahwa struktur aset berhubungan positif dengan kebijakan hutang, hal ini mengartikan bahwa setiap kenaikan struktur aset akan diikuti dengan kenaikan hutang, dengan asumsi pertumbuhan penjualan dan kepemilikan manajerial tidak berubah.

Hasil uji hipotesis pertumbuhan penjualan menunjukkan t-hitung sebesar 1,320 dengan t-tabel 2,056, sehingga t-hitung < t-tabel dan nilai signifikansi sebesar 0,198 yang berarti lebih besar dari probabilitas 0,05 atau $0,198>0,05$ maka hipotesis dua $\left(\mathrm{H}_{2}\right)$ ditolak, yang berarti variabel independen pertumbuhan penjualan tidak berpengaruh signifikan terhadap kebijakan hutang. Nilai koefisien pertumbuhan penjualan $\left(\mathrm{X}_{2}\right)$ bernilai positif 0,251 . Hal ini menunjukkan bahwa pertumbuhan penjualan berhubungan positif dengan kebijakan hutang, sehingga jika terjadi kenaikan pertumbuhan penjualan, maka akan diikuti dengan kenaikan hutang dengan asumsi struktur aset dan kepemilikan manajerial tidak berubah.

Hasil uji hipotesis kepemilikan manajerial menunjukkan hasil t-hitung sebesar 1,000 dengan t-tabel 2,056 atau t-hitung $1,000<$ t-tabel 2,042 dan nilai signifikansi sebesar 0,326 yang berarti lebih kecil dari probabilitas 0,05 atau $0,326<0,05$, maka hipotesis $\left(\mathrm{H}_{3}\right)$ ditolak. Jadi variabel independen kepemilikan manajerial tidak berengaruh signifikan terhadap kebijakan hutang, artinya bahwa semakin tinggi tingkat kepemilikan manajerial dalam perusahaan tidak berpengaruh besar terhadap kenaikan penggunaan hutang. Nilai koefisien kepemilikan manajerial sebesar 0,182 , hal ini menunjukkan bahwa kepemilikan manajerial berhubungan positif dengan kebijakan hutang, sehingga jika terjadi kenaikan kepemilikan manajerial, maka nilai hutang akan meningkat. dengan asumsi struktur aset dan pertumbuhan penjualan tidak berubah.

\section{Pembahasan}

\section{Pengaruh struktur aset terhadap kebijakan hutang}

Peningkatan struktur aset mendorong peningkatan kebijakan hutang, sehingga dapat dikatakan jika nilai aset tetap suatu perusahaan tinggi akan mendorong penggunaan hutang yang lebih besar juga. Hal ini membuktikan bahwa meningkatnya aset tetap (fixed asset) membuat perusahaan dapat menggunakan hutang yang lebih banyak, atau dengan kata lain. Hal ini memungkinkan, karena semakin tinggi jumlah aset tetap dalam struktur aset perusahaan, semakin mempermudah 
perusahaan untuk mendapatkan hutang, sehingga aset tetap tersebut dapat dijadikan sebagai jaminan bagi kreditur. Hal ini sesuai dengan trade off theory bahwa aset tetap digunakan sebagai persyaratan melakukan pinjaman, sehingga semakin besar nilai aset tetap maka ada kecenderungan semakin besar pula pinjaman yang diperoleh perusahaan.

Menurut Brigham dan Houston (2006), secara umum perusahaan yang memiliki jaminan, akan lebih mudah memperoleh utang daripada perusahaan yang tidak mempunyai jaminan. Penelitian yang dilakukan oleh Sujarweni (2014) bahwa terdapat pengaruh antara struktur aset terhadap kebijakan hutang. Penelitian yang dilakukan oleh Destisa (2018) bahwa struktur aset berpengaruh terhadap kebijakan hutang pada perusahaan property dan real estate. Struktur aset dijadikan bahan pertimbangan perusahaan dalam menentukan besarnya hutang yang akan diambil. Berbeda dengan penelitian yang dilakukan oleh Yati (2016) bahwa struktur aset tidak berpengaruh terhadap kebijakan hutang. Hal tersebut dikarenakan apabila perusahaan mencari hutang sebagai sumber pendanaan utama akan semakin besar biaya modal yang dikeluarkan.

Penelitian ini sejalan dengan hipotesis yang diajukan yang mengatakan bahwa struktur aset berpengaruh terhadap kebijakan hutang. Hasil penelitian ini sesuai dengan penelitian Ramadhany, et al (2015), Ita (2016), Surya dan Rahayuningsih (2012), Sujarweni (2014), Destisa (2018) yang menyatakan bahwa struktur aset memiliki pengaruh yang signifikan dan berhubungan positif terhadap kebijakan hutang.

\section{Pengaruh pertumbuhan penjualan terhadap kebijakan hutang}

Peningkatan pertumbuhan penjualan mendorong peningkatan kebijakan hutang, walaupun tidak begitu besar, artinya bahwa semakin tinggi tingkat pertumbuhan penjualan suatu perusahaan tidak diikuti dengan penggunaan hutang yang tinggi pula. Hal ini mengindikasikan pula bahwa kenaikan penjualan memungkinkan perusahaan memiliki sumber pendanaan internal.

Menurut Bringham dan Houston (2010), perusahaan dengan tingkat penjualan dan laba yang tinggi akan cenderung menggunakan hutang sebagai sumber pendanaan eksternal yang lebih besar dibandingkan perusahaan yang tingkat penjualannya rendah. Penelitian yang dilakukan oleh Yati (2016) bahwa pertumbuhan penjualan berpengaruh signifikan terhadap kebijakan hutang. Hal ini menunjukkan bahwa pertumbuhan penjualan mencerminkan keberhasilan investasi periode di masa lalu. Ketika dana internal berupa pendapatan penjualan tidak dapat mencukupi, perusahaan dengan aman menggunakan hutang karena penjualan yang stabil. Penelitian yang dilakukan oleh Umi (2018) bahwa pertumbuhan penjualan berpengaruh positif signifikan terhadap kebijakan hutang. Hal ini dikarenakan perusahaan yang memiliki tingkat pertumbuhan yang tinggi cenderung membutuhkan sumber dana dari eksternal yang lebih besar. Selain itu, para investor akan menilai dan yakin pada perusahaan jika perusahaan tersebut mengelola utangnya dengan baik. Berbeda dengan penelitian yang dilakukan oleh Faria (2014) bahwa pertumbuhan penjualan tidak berpengaruh terhadap kebijakan hutang pada perusahaan. Hal ini disebabkan jika pertumbuhan penjualan dibiayai dengan hutang, manajer tidak akan melakukan investasi yang optimal dan pertumbuhan penjualan yang dialami perusahaan tersebut menyebabkan perusahaan membutuhkan dana lebih, maka kemungkinan mereka akan menerbitkan saham untuk mengumpulkan dana yang mempunyai borrowing cost yang lebih rendah daripada hutang.

Penelitian ini sejalan dengan penelitian yang dilakukan Susanti (2014), dan Faria (2014) bahwa pertumbuhan penjualan tidak berpengaruh signifikan 
terhadap kebijakan hutang pada perusahaan, hal ini menunjukkan tidak semua perusahaan yang mempunyai tingkat pertumbuhan penjualan yang tinggi memilih hutang sebagai sumber pendanaannya. Dalam hal ini, dikarenakan nilai pertumbuhan penjualan dari tahun ke tahun berfluktuasi membuat pihak manajemen perusahaan merasa bahwa kondisi tersebut merupakan pertanda yang kurang baik bagi perusahaan. Perusahaan cenderung akan tetap memilih sumber pendanaan yang mempunyai borrowing cost yang lebih murah dan lebih mengandalkan dana internal.

\section{Pengaruh kepemilikan manajeriap terhadap kebijakan hutang}

Peningkatan kepemilikan

manajerial mendorong peningkatan kebijakan hutang, walaupun tidak begitu besar, sehingga dapat dikatakan jika semakin tinggi tingkat kepemilikan manajerial dalam perusahaan akan mendorong penggunaan hutang yang tidak begitu besar. Artinya bahwa semakin tinggi tingkat kepemilikan manajerial suatu perusahaan tidak diikuti dengan penggunaan hutang yang tinggi pula. Penelitian ini tidak sejalan dengan hipotesis yang mengatakan bahwa kepemilikan manajerial berpengaruh signifikan terhadap kebijakan hutang.

Dalam agency theory, hubungan antara manajer dan pemegang saham digambarkan sebagai hubungan antara agent dan principal (Schroeder, et. al, 2001). Kepemilikan manajerial menggambarkan suatu peran ganda, yaitu sebagai manajer dan juga pemegang saham dimana masingmasing memiliki kepentingan. Penelitian yang dilakukan oleh Umi (2018), dan Ita (2016) bahwa kepemilikan manajerial tidak berpengaruh terhadap kebijakan hutang. Hal ini menandakan bahwa besar kecilnya kepemilikan saham oleh pihak manajerial tidak mendukung keputusan pendanaan dan kebijakan hutang perusahaan. Namun berbeda dengan penelitian yang dilakukan oleh Sheisarvian (2015) bahwa kepemilikan manajerial berpengaruh signifikan terhadap kebijakan hutang.

Hasil penelitian ini sesuai dengan penelitian Mardiyati, et al (2018) yang menyatakan bahwa kepemilikan manajerial secara parsial tidak memiliki pengaruh terhadap kebijakan hutang. Oleh karena dalam perusahaan kepemilikan saham juga dimiliki oleh pihak lain (public), manajer tidak dapat mengambil keputusan berdasarkan keinginannya sendiri. Dengan kata lain, manajer tidak dapat menggunakan wewenangnya untuk menentukan sumber pendanaan.

\section{KESIMPULAN DAN SARAN}

\section{Kesimpulan}

1. Peningkatan struktur aset mendorong peningkatan kebijakan hutang, sehingga kenaikan aset perusahaan akan mendorong naiknya hutang, terutama bila aset tersebut dibiayai dengan hutang.

2. Peningkatan pertumbuhan penjualan mendorong peningkatan kebijakan hutang, namun semakin tinggi tingkat pertumbuhan penjualan suatu perusahaan tidak diikuti dengan penggunaan hutang yang tinggi pula.

3. Peningkatan kepemilikan manajerial mendorong peningkatan kebijakan hutang, namun semakin tinggi tingkat kepemilikan manajerial dalam perusahaan tidak diikuti dengan penggunaan hutang yang tinggi pula.

\section{Saran}

1. Pihak manajemen harus mampu menjaga struktur asetnya agar mampu mendorong kinerja perusahaan secara efektif.

2. Pihak manajemen perlu mendorong pertumbuhan penjualan menjadi hal 
yang sangat penting untuk diperhatikan.

3. Pihak manajemen selalu menjaga keseimbangan struktur kepemilikan. Hal ini akan memberikan manfaat, sehingga potensi perbedaan kepentingan antara pemegang saham dan manajemen dapat diselaraskan, agar tujuan dari setiap perusahaan yaitu memaksimalkan keuntungan pemegang saham dapat terealisasikan.

\section{DAFTAR PUSTAKA}

Azhari, Hidayat. 2013. Pengaruh Kebijakan Hutang dan Kebijakan Deviden terhadap Nilai Perusahaan. Artikel. Universitas Negeri Padang.

AMD Yuniarti, Pengaruh Kepemilikan Manajerial, Profitabilitas, Struktur Aset, dan Kebijakan Deviden terhadap Kebijakan Hutang. Accounting analisis Journal 2013. Journal unnes ac.id volume 2 No 4 tahun 2013

Anam, Hairul, et al. 2015. Pengaruh Struktur Aset, Ukuran Perusahaan dan Pertumbuhan Perusahaan terhadap Kebijakan Hutang (Studi pada Perusahaan Farmasi Periode 2010-2014). Jurnal \& Proceeding Universitas Jenderal Sudirman Vol. 5 No 1 tahun 2015

Brigham, E.F. dan Houston, J.F. 2014. Dasar-Dasar Manajemen Keuangan. Edisi Kesepuluh. Jakarta: Salemba Empat.

Djahidin, Farid. 2013. Analisa Laporan Keuangan. Ghalia Indonesia. Jakarta.

Fahmi, Irham. 2012. Analisis Laporan Keuangan. Cetakan Kedua. Bandung. Alfabeta.

Ghozali, Imam. 2012. Aplikasi Analisis Multivariate dengan Program IBM SPSS. Yogyakarta: Universitas Diponegoro
Halim, Abdul dan Mamduh M. Hanafi. 2009. Analisis Laporan Keuangan. Edisi 4. UPP STIM YKPN. Yogyakarta.

Harahap, Sofyan. 2016. Analisis Kritis atas Laporan Keuangan. Jakarta : PT Raja Grafindo Persada.

Hery. 2014. Analisis Laporan Keuangan. Jakarta: Bumi Aksara.

Hery. 2016. Analisis Kinerja Manajemen. Jakarta : PT Grasindo.

Hidayat, Syafiudin. 2013. Pengaruh Kepemilikan Manajerial, Kebijakan Deviden, Struktur Aset, Pertumbuhan Penjualan, dan Ukuran Perusahaan terhadap Kebijakan Hutang. Jurnal Ilmu Manajemen (JIM) Univ. Negeri Surabaya Vol. 1 No 1 tahun 2013

Indrastanti, S. R et al. 2011. Manajemen Keuangan II. Surakarta.

Kasmir. 2016. Analisis Laporan Keuangan. Edisi dua. Cetakan Kelima. Jakarta. Raja Grafindo Persada.

Khusniyah, et al. 2018. Pengaruh Kepemilikan Manajerial, Kepemilikan Institusional, Kebijakan Deviden, Profitabilitas terhadap Kebijakan Hutang (Studi Empiris Perusahaan Manufaktur yang Terdaftar di BEI 2012-2016). Universitas Islam Malang. E-JRA Vol. 07 No. 11 Agustus 2018 http://riset.unisma.ac.id/index.php/jr a/article/viewFile/1484/1456

Larasati, Eva. 2011. Pengaruh Kepemilikan Manajerial, Kepemilikan Institusional dan Kebijakan Dividen terhadap Kebijakan Hutang Perusahaan. Universitas Tadulako. Jurnal Ekonomi Bisnis, Th. 16, No. 2, Juli 2011

Mardiyati, Umi, et al. 2018. Pengaruh Kepemilikan Manajerial, Struktur Aset, Ukuran Perusahaan, Pertumbuhan Penjualan, Profitabilitas terhadap Kebijakan Hutang Pada Perusahaan Sektor 
Aneka Industri yang Terdaftar di BEI 2012-2016. Universitas Negeri Jakarta. Jurnal Riset Manajemen Sains Indonesia Vol 9 No 1 (2018): https://doi.org/10.21009/JRMSI.009. 1.08

Munawir. 2013. Analisis Laporan Keuangan. Edisi Keempat. Yogyakarta. Liberty.

Ramadhany, Reza, et al. 2015. Analisis Faktor yang Mempengaruhi Kebijakan Hutang Emiten Pertanian di BEI. Institut Pertanian Bogor. Jurnal Manajemen dan Organisasi Vol. 6 No. 3 (2015):

Sugiyono. 2010. Metode Penelitian Kuantitatif , Kulitatif dan R\&D. Bandung. Alfabeta.

Sugiyono. 2017. Metode Penelitian Kuantitatif, Kualitatif, dan $R \& D$. Bandung. Alfabeta.

Sujarweni, W.V. 2017. Analisa Laporan

Keuangan. Yogyakarta. Pustaka Baru Press.

Sheisarvian Revi Maretta 2015. Pengaruh Kepemilikan Manajerial, Kebijakan Deviden, dan Profitabilitas terhadap Kebijakan Hutang (Studi pada Perusahaan Manufaktur yang Terdaftar di BEI 2010-2012). Universitas Brawijaya. Jurnal Administrasi Bisnis, 2015 VOL 22, NO 1 (2015)

Susanti- Faria Pengaruh Likuiditas, Kebijakan Deviden, Struktur Aset, Ukuran Perusahaan Dan Pertumbuhan Penjualan Terhadap Kebijakan Hutang Pada Perusahaan Manufaktur Yang Terdaftar Di Bursa Efek Indonesia Tahun 20102013 http://jurnal.umrah.ac.id/wpcontent/uploads/gravity_forms/1ec61c9cb232a03a96d0947c6478e52 5e/2016/08/ -JURNAL.pdf

Sujarweni, et al. 2014. Faktor-Faktor yang Mempengaruhi Kebijakan Hutang (Studi Empiris Perusahaan Manufaktur yang Terdaftar di BEI 2009-2012). Universitas Muhammadiya Yogyakarta. Jurnal
Bisnis Teori dan Implementasi Vol. 5 No 1 tahun 2014

Surya, Dennys dan Rahayuningsih, Ariyanti, 2012, Faktor-

Faktor Yang Mempengaruhi

Kebijakan Hutang Perusahaan Non Keuangan Yang Terdaftar Dalam Bursa Efek Indonesia, Univ. Pandanaran. Jurnal Bisnis dan Akuntansi, Vol. 14, No. 3, tahun 2012,

Trisnawati, Ita. 2016. Faktor-faktor Yang Mempengaruhi Kebijakan Hutang pada Perusahaan Non-Keuangan yang Terdaftar di Bursa Efek Indonesia. STIE Trisakti. Jurnal bisnis dan akuntansi, Vol 18 No 1 tahun 2016

Warapsari, et al. 2016. Pengaruh Kepemilikan Manajerial, Kepemilikan Institusional terhadap Nilai Perusahaan dengan Kebijakan Hutang sebagai Variabel Intervening. E-Jurnal Akuntansi Universitas Udayana, Vol.16.3. September (2016): 2288-2315

Weston Fred J dan Thomas E. Copeland, 2012. Manajemen Keuangan. Jilid I. Edisi Kedelapan. Terjemahan Jaka Wasana dan Kirbranoka, Erlangga, Jakarta.

Yati, Mulyati. 2016. Pengaruh Struktur Aset, dan Pertumbuhan Penjualan terhadap Kebijakan Hutang. Universitas Jember. UNEJ $e$ Proceeding, [S.l.], p. 813-831, dec. 2016. ISSN 2686-0783. http://jurnal.unej.ac.id/index.php/pr osiding/article/view/3694 
